\title{
Evaluation of proximate, fibre qualities and consumer acceptability of bambaranut - tigernut - coconut milk beverage blends
}

\author{
Adedokun I. I. ${ }^{1, *}$, Okorie, S. U. ${ }^{2}$, Batu Barizaa ${ }^{2}$ \\ ${ }^{1}$ Department of Food Science and Technology, Imo State Polytechnic Umuagwo-Ohaji, Imo State, Nigeria \\ ${ }^{2}$ Department of Food Science and Technology, Faculty of Engineering, Imo State University, Owerri, Imo State, Nigeria \\ Email address: \\ ishola66@yahoo.com (Adedokun I. I.), stanudeokorie@gmail.com (Okorie, S. U.)
}

\section{To cite this article:}

Adedokun I. I., Okorie, S. U., Batu Barizaa. Evaluation of Proximate, Fibre Qualities and Consumer Acceptability of Bambaranut Tigernut - Coconut Milk Beverage Blends. International Journal of Nutrition and Food Sciences. Vol. 3, No. 5, 2014 , pp. $430-437$. doi: $10.11648 /$ j.ijnfs.20140305.20

\begin{abstract}
Proximate composition and consumer acceptability of bambaranut-tigernut-coconut milk beverage blends was conducted. Four blends of milk beverage were formulated using different ratios of 1:1:1, 3:2:1, 2:3:1 and 1:3:2 from single milk extraction from babaranut, tigernut and coconut. Two control samples were made from 100\% bambaranut and tigernut milk respectively. The samples were subjected to proximate and dietary fiber analysis and sensory evaluation were conducted. The mean score of sensory attribute of the milk beverage blends was significantly different $(\mathrm{P}<0.05)$. Generally, the blend made from ratio 1:3:2 of bambaranut - tigernut - coconut milk mix having the highest mean score of 8.60 was the most rated and the best among the sample blends. The proximate composition parameters varied among the blends with highest values detected on the samples as follows: moisture $81.22 \%$, crude protein $6.28 \%$, fat $4.30 \%$, crude fiber $2.12 \%$, ash content $2.30 \%$ and $11.82 \%$ for total carbohydrates. The total dietary fibre of the blends was within the range of $0.78-$ $2.10 \%$.
\end{abstract}

Keywords: Proximate, Consumer, Acceptability, Bambaranut- Tigernut - Coconut, Milk Beverage Blends

\section{Introduction}

The value of milk in relieving malnutrition especially among the growing infant in the developing countries is particularly note worthy. In developing countries, the cost of dairy milk and their products are expensive for commoners to purchase. The dramatic decrease in the consumption of milk and milk products stimulated in part the processing of milk from different seeds and nuts (1). Though undervalued in the past, milk from plant sources are key ingredients in the diet of African countries. Recently, researchers have shown strong interest in these milk sources due to their high nutritional values and economic potentials. It is worth repeating that milk sources from plants are seen as a radiating hope as well as an ally in the fight against hidden hunger ${ }^{(2)}$. In view of the scarce milk supply in various countries and the ever increasing gap between the requirement and population, efforts have been made over the years to develop alternative 'milk analogue' products from vegetable sources ${ }^{(3)}$. 'Milk analogue' is as an extract which has been derived from sources other than dairy origin, usually of single or a blend of vegetable extract in form of liquid, powdered, evaporated, or in condensed form with or without the addition of additives and close resemblance of cow milk ${ }^{(1,4)}$.

Legume crops especially soybeans among others have received very high research attention and more research is still being designed to improve the quality of soy milk ${ }^{(5)}$ yet supply and demand has not been met due to increasing world population apart from its high cost like cow milk. However, little research attention has been given to bambaranut ${ }^{(6)}$, baobab ${ }^{(7)}$, peanut ${ }^{(8)}$, melon seed ${ }^{(4)}$ and tigernut milk ${ }^{(9)}$ as sources of single or blended ready-toserve bottled beverage, like "Horchata de chufas" as done in South Europe, especially Spain.

Tiger-nut (Cyperus esculentus L.) belongs to the Division - Magnoliophyta, Class - Liliopsida, Order Cyperales and Family - Cyperaceae and was found to be a cosmopolitan, perennial crop of the same genus as the 
papyrus plant ${ }^{(2)}$. The tubers are about the size of peanuts and are abundantly produced in Nigeria. It has many other names like Zulu nut, yellow nut grass, ground almond, chafu, edible rush and rush nut. In Nigeria, the Hausas call it "Aya", Yorubas "imumu" the Igbos "aki Hausa", "ofio" in southern Nigeria ${ }^{(10)}$. Tigernut, an under-utilized crop, report showed that the nut itself has $5.8 \%$ moisture, rich in protein $(7 \%)^{(11)}$ and carbohydrate such as reducing sugar (7.4\%), soluble polysaccharide (7.4\%) and starch $(86.4 \%)$ (12). According to Ojobe and Tempo ${ }^{(13)}$, the protein in tigernut is of high biological value considering the many essential amino acids it contains. These amino acids are higher than those proposed in the standard by the FAO/WHO ${ }^{(14-15)}$ and satisfy amino acid need of adults ${ }^{(16)}$. Despite its nutritional and economical values, its potential as raw material has been under-utilized in food industry in most developing nations of the tropic due to inconsistencies in the results of research carried out in the past.

Bambara groundnut (Vigna subterranean (L.) Verdc.) is an African species, the cultivation of which predates that of groundnut. Report (17) noted that in Nigeria, bambara groundnut is widely produced in Borno, Anambra, Plateau, Taraba, Sokoto, Bauch, Benue, Kano, Yobe, Adamawa and Gombe states (18). Bambara groundnut as reported (19) contains crude protein $20.60 \%$, it is high in lysine with fair amount of total sulphur amino acids. The seed is deficient in tryptophan, the bulk of the fat is unsaturated (about 59\%) while $41 \%$ is saturated ${ }^{(19)}$. Akande, et al, ${ }^{(17)}$ stated that the seed of bambara groundnut can be used for baby food, human consumption, industrial products and for animal feed. Despite its economic importance, no noticeable industrial use of the crop has taken place in Nigeria upon its high annual yield ${ }^{(1)}$.

Coconut (Cocus nucifera) is the stone of the drupes borne by the coconut palm, a member of the monocotyledonous family Palmae. It is known as the "wonder food" and is regarded as perfect diet because it contains almost all essential nutrients needed by the human body ${ }^{(20)}$.

Coconut (Cocus nucifera) milk is being used by confectionaries, bakeries, biscuits and ice cream industries worldwide to enhance flavor and taste of various products (21). Coconut milk as found to be rich in calcium $(800 \mathrm{mg} / 100 \mathrm{~g})$ while the protein and fat contents were $2.02 \mathrm{~g} / 100 \mathrm{~g}$ and $21.33 \mathrm{~g} / 100 \mathrm{~g}$ respectively. The energy content was 197 kilocalories/100g and the total available carbohydrate was $2.81 \mathrm{~g} / 100 \mathrm{~g}$. ${ }^{(22-23)}$. Therefore, the present research was aimed towards evaluation of proximate and dietary fibre characteristics, consumer acceptability and yield of mixed milk analogue from three different local food materials. This work examined the effect of methods of processing on the proximate composition, dietary fiber and consumers' acceptability of vegetable milk beverage blends.

\section{Materials and Methods}

\subsection{Material Collection}

Two of the local raw materials (Bambara-nut and Tigernut) were purchased from Ama-Hausa Market, Owerri. Freshly harvested coconut fruits were obtained from a local farm located at Umuagwo in Ohaji-Egbema L.G.A of Imo State. Sucrose (sweetener) and food grade emulsifier was purchased from De-Cross Ltd Lagos. Serile pre-formed plastic bottles were obtained from Tenth April Ltd Mbieri Area Mbaitoli L.G.A for packaging and storage.

\subsection{Preparation of Bambaranut Milk}

The method described by Adedokun et al, ${ }^{(1)}$ (Figure 1) for the production of milk substitute was used in the extraction of bambara-nut milk. The nuts of babaranut 'Nav Red' variety was manually sorted, cleaned with portable water and soaked in $(4.1 \mathrm{w} / \mathrm{v})$ portable waster for $24 \mathrm{~h}$, water used in soaking was changed at every $6 \mathrm{hr}$ interval during the soaking duration. The seed coat of the nuts was dehulled after $8 \mathrm{~h}$ of soaking by rubbing the seeds with the palm and the husks were sieved out of the water and subsequently wet milled using hammer mill. Cheese cloth was used in the extraction of milk from the bambaranut mash triple filtered by folding the cheese cloth thrice and stored in a sterile white container for further use.

\subsection{Tiger-Nut Milk}

The method described by Udeozor ${ }^{(24)}$ (figure 2) was modified for the extraction of tiger-nut milk. One kilogram $(1 \mathrm{~kg})$ of the fresh tiger nuts was manually sorted and cleaned to remove foreign particles and unwanted materials. The nuts were soaked in portable water at ratio nut: water (1:3) overnight. The soaked nut was milled into slurry using attrition several times with addition of $3 \mathrm{~L}$ of water. The slurry was pressed using muslin cloth to extract the milk. The extracted liquor homogenized using Q-Link Blender (Model 365XG), cooled and stored in a white sterile 4litre container.

\subsection{Preparation of Coconut Milk Extract}

The method (Figure 3) described by Belewu and Belewu ${ }^{(2)}$ was used in the extraction of coconut milk. Coconut milk was prepared by shelling the nut and the meat was separated from the shell using a dull knife. The brown skin was removed from the coconut meat with a razor blade and the meat was thoroughly washed and grated using attrition mill. The grated meat was put in a bowl and litter warm water was added and left for a few minutes to extract the oil, milk and the aromatic compounds with cheese cloth. The extract was filtered with $0.18 \mathrm{~mm}$ sieve and squeezed, to obtain a milky-white opaque emulsion with a sweet coconut flavor while the chaff was discarded. 


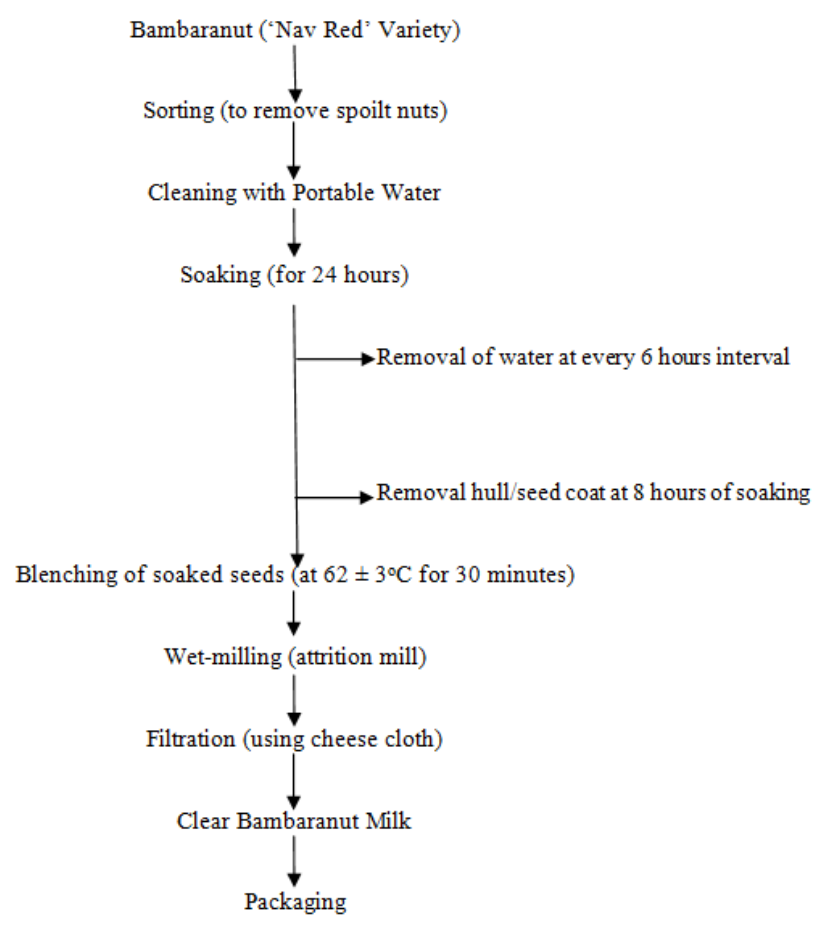

Figure 1. Flow chart for the production of Bambaranut Milk

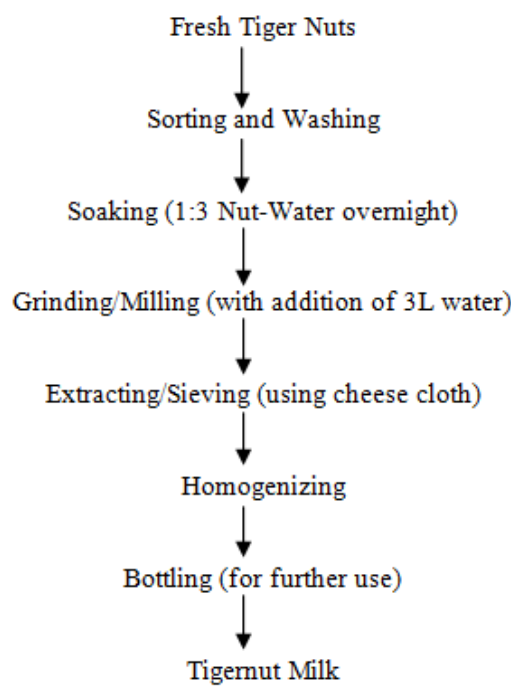

Figure 2. Flow chart for the production of Tigernut Milk

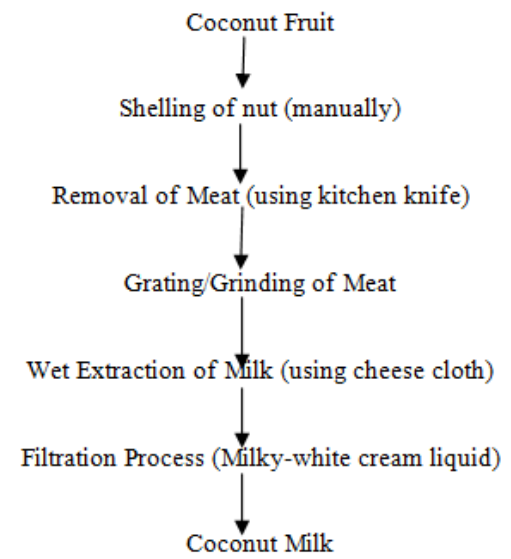

Figure 3. Flow chart for the processing of Coconut Milk

\subsection{Production of Bambaranut-Tigernut-Coconut Milk Beverage (BTCB)}

Unpasteurized Bambara\nut Milk (BM), Tigernut Milk (TM) and Coconut Milk (CM) was mixed together using varying ratio of $1: 1: 1$ (BTCB1); 3:2:1 (BTCB2); 2:1:3 (BTCB3); 1:3:2 (BTCB4). Two control samples were made from a single bambaranut milk and tigernut milk. Each blend and single mix was sweetened with sugar syrup of $4 \%$ suspension solution in water and final emulsified with lecithin. The resultant mixture was homogenized at maximum speed in a Q-Link Blender (Model $356 \mathrm{XG}$ ) for 10 minutes. The product was pasteurized at $65^{\circ} \mathrm{C}$ for 30 minutes and bottled, then cooled under ambient condition as showed in Figure 4.

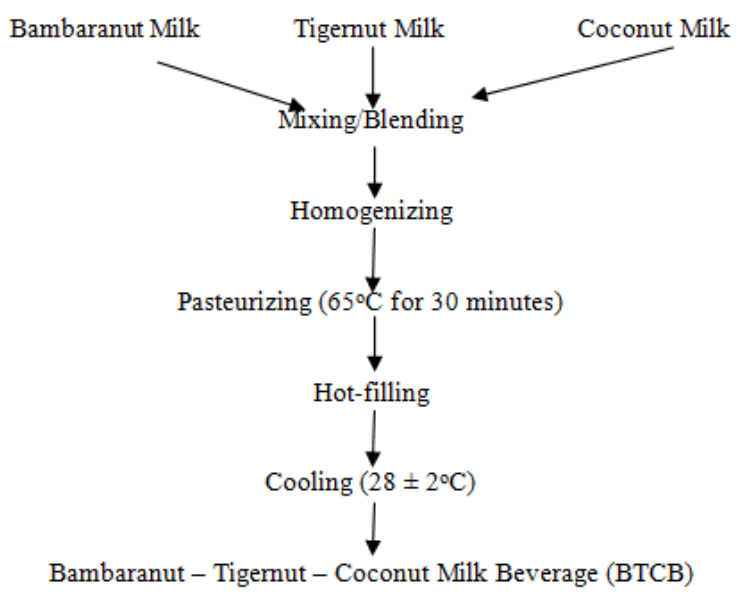

Figure 4. Flow chart for the production of Bambaranut - Tigernut Coconut Milk Beverage (BTCB)

\subsection{Proximate Analysis}

The standard method of the A.O.A.C ${ }^{(25)}$ was used for the analysis of the proximate composition of the samples.

\subsection{Moisture Content}

The standard method of the A.O.A.C ${ }^{(25)}$ was used. Two gram-portions $(2 \mathrm{~g})$ of each grated samples were weighed into previously weighed dry crucibles with lid. The crucibles with samples were then dried in an oven (Astel Hearson, England), at $105^{\circ} \mathrm{C}$ for 24 hours. The crucibles with contents were cooled in a desiccators and weighted, then put back into the oven and the operation was repeated until a constant weight was obtained. The loss in weight obtained represented the moisture content and was calculated with the following formula:

$$
\% \text { Moisture Content }=\frac{\mathrm{W}_{1}-\mathrm{W}_{2}}{\mathrm{~W}_{1}} \times \frac{100}{1}
$$

Where

$\mathrm{W}_{1}=$ The weight of sample before drying

$\mathrm{W}_{2}=$ The weight of sample after drying 


\subsection{Ash Content}

The ash content was determined by the furnace incineration method described by A. O. A. ${ }^{(25)}$.

A $2 \mathrm{~g}$ portion of each sample was weighed into previously weighted and dried porcelain crucibles. The crucible and sample were placed in the muffled furnace at $550^{\circ} \mathrm{C}$ for 4 hours (until a grey ash was left). The ash left in the crucible was cooled in a desiccator and reweighted. The ash content was calculated as:

$$
\% \text { Ash }=\frac{\mathrm{W}_{1}-\mathrm{W}_{2}}{\text { Weight of Sample }} \times \frac{100}{1}
$$

Where

$\mathrm{W}_{1}=$ The weight of empty crucible

$\mathrm{W}_{2}=$ The weight of crucible and ash

\subsection{Crude Protein Content}

The crude protein was determined using the MicroKjedahl Technique ${ }^{(25)}$. One gram (1g) portion of each sample was weighted into filter paper and added into the dry digestion Kjedahl flask, followed by $0.12 \mathrm{~g}$ of copper sulphate $\left(\mathrm{CuSO}_{4}\right)$. Two and half grams $(2.5 \mathrm{~g})$ of sodium sulphate $\left(\mathrm{Na}_{2} \mathrm{SO}_{4}\right)$; and $2.50 \mathrm{ml}$ of concentrated sulphuric acid $\left(\mathrm{H}_{2} \mathrm{SO}_{4}\right)$ were added with $3 \mathrm{~g}$ selenium catalyst and a few anti-bumping chips. It was then heated in a flame chamber until the solution became clear (colourless). The solution was cooled to room temperature after which $80 \mathrm{ml}$ of distilled water was added. Then, $50 \mathrm{ml}$ of $2 \%$ boric acid was placed in the receiving flask under the condenser with two drops of methyl red indicator added. The digestion flask was heated until $100 \mathrm{ml}$ distillate was collected. And $10 \mathrm{ml}$ of the distillate was titrated with $0.649 \mathrm{M} \mathrm{H}_{2} \mathrm{SO}_{4}$ to get pink colour. The same procedure was carried out on the blank.

The amount of nitrogen was calculated.

Weight of sample $=1.0 \mathrm{~g}$

Volume of $\mathrm{H}_{2} \mathrm{SO}_{4}$ required for the titration $=2.50 \mathrm{ml}$

Normality of $\mathrm{H}_{2} \mathrm{SO}_{4}=\mathrm{N}$

Nitrogen \% of Sample (\%N)

$=\frac{\text { Titer }- \text { Blank X Normality of Acid X N Factor }}{\text { Weight of Sample }}$

\section{Crude Protein $=\%$ N X 6.25}

\subsection{Determination of Crude Fat Content}

The standard method of the A.O.A.C ${ }^{(25)}$ was used. A $250 \mathrm{ml}$ extraction flask was washed, dried in the oven, cooled in a desiccators and weighed. The Soxhlet extractor was fitted with a reflux condenser and $3 \mathrm{~g}$ of the dried ground sample was weighed into a filter paper, folded and transferred into a $50 \mathrm{~mm} \times 10 \mathrm{~mm}$ extraction thimble and plugged lightly with a cotton wool. The thimble as placed in the extraction barrel and petroleum ether added until it siphoned over once in the flask directly below it. The flask was then heated and refluxed for seven hours. The thimble was then removed from the barrel and the solvent distilled off until the extraction flask was almost dry. The flask containing the fat was dried in the oven to a constant weight at $40^{\circ} \mathrm{C}$ to evaporate the solvent completely, then cooled in a desiccator and weighed.

The difference in weights obtained was used to calculate as the $\%$ crude fat.

$$
\% \text { Crude Fat }=\frac{\mathrm{W}_{2}-\mathrm{W}_{1}}{\text { Weight of Sample }} \times \frac{100}{1}
$$

Where

$\mathrm{W}_{1}=$ Weight of empty flask

$\mathrm{W}_{2}=$ The weight of sample with extracted fat

$\mathrm{W}_{\mathrm{t}}=$ Weight of sample

\subsection{Determination of Crude Fiber}

Twenty milliliters $(20 \mathrm{ml})$ of $0.1 \mathrm{M} \mathrm{H}_{2} \mathrm{SO}_{4}$ was poured into a $100 \mathrm{ml}$ conical flask containing $2 \mathrm{~g}$ of the defatted sample. The flask was fitted to a reflux condenser. Another $180 \mathrm{ml}$ of boiling dilute sulphuric acid was added into this flask and heat applied so that the entire liquid started boiling in $1 \mathrm{~min}$. The refluxing was continued for 30 minutes with occasional shaking to bring down any particles attached to the side. A funnel was fitted with a filter paper (Whatman 54) and boiling water poured into the funnel and allowed to stand until the funnel was hot. The water was then drained by suction. Then the hot acid mixture was poured immediately into a shallow layer of hot water into the funnel. The suction was adjusted so that the filtration of the bulk of $200 \mathrm{ml}(20 \mathrm{ml}+180 \mathrm{ml})$ was completed within 10 minutes. The residue in the filter paper was washed with boiling water until the washing was acid free. Again, the residue was washed back into the original flask containing $200 \mathrm{ml}$ of hot $0.3 \mathrm{M} \mathrm{NaOH}$. The liquid was boiled for 30 minutes and filtered taking the same precautions as before. Again, the residue in the filter was washed with boiling water, then with $1 \% \mathrm{HCl}$ and finally with boiling water until the washings was free from acid. The residue was then washed with ethanol. The insoluble matter was carefully transferred into a dry and weighed crucible by means of a spatula, taking care not to dislodge any fiber from the filter paper. The crucible was dried in the oven at $70^{\circ} \mathrm{C}$ for 2 hours, cooled in a desiccators and weighed. The residue was then ashed into the furnace at $550^{\circ} \mathrm{C}$ for 3 hours, cooled in a desiccators and weighed.

Calculation:

Weight loss during ignition is the weight of the fiber

$$
\% \text { Fiber }=\frac{\text { Weight of Fiber }}{2} \times \frac{100}{1}
$$

Where 2 = The original weight of defatted sample

\subsection{Total Carbohydrate}

The standard method of the A.O.A.C ${ }^{(25)}$ was used. This was determined by the differences between the whole 
sample and the sum of the liquid, ash, protein, and the fiber composition of the sample.

$$
\begin{gathered}
\% \text { Carbohydrate }=100-[\% \text { Protein }+\% \text { Fat }+\% \text { Ash }+\% \\
\text { Crude Fiber }]
\end{gathered}
$$

\subsection{Dietary Fiber Analysis}

For soluble and insoluble dietary fiber, method described by A.A.C.C ${ }^{(26)}$ was followed.

\subsubsection{Reagents}

Mes-Tris blend buffer, Heat stable, Alpha-amylase, Protease, Amyloglucoidase, $5 \mathrm{ml}$ of $0.561 \mathrm{~N} \mathrm{HCl}, 5 \% \mathrm{NaOH}$ or $5 \% \mathrm{HCl}, 95 \%$ ethanol, Acetone, and $78 \%$ ethanol.

\subsubsection{Apparatus}

$400 \mathrm{ml}$ beaker, $\mathrm{p}^{\mathrm{H}}$ meter, magnetic stirrer and stirring bars, fritted crucible, filtration flask, rubber ring adaptor, vacuum pump, shaking water bath, balance, muffle furnace, ovens, timer, desiccators, pipette and tips $(100-1300 \mu \mathrm{l}$ and $5 \mathrm{ml})$, dispensers, measuring cylinders and rubber spatulas.

\subsubsection{Procedure}

One gram of the dry sample was weighed into $400 \mathrm{ml}$ beaker and $40 \mathrm{ml}$ of Mes-Tris blend buffer at $\mathrm{p}^{\mathrm{H}} 8.2$ was added while stirring, after which $2 \mathrm{ml}$ heat stable alphaamylase was added. The $400 \mathrm{ml}$ beaker was placed in water bath at $95-100^{\circ} \mathrm{C}$ for 35 minutes. It was allowed to cool to $60^{\circ} \mathrm{C}$ and rinsed with $10 \mathrm{ml}$ of distilled water. Thus, $0.1 \mathrm{ml}$ of protease solution $(50 \mathrm{mg} / \mathrm{ml})$ was added and incubated at $60^{\circ} \mathrm{C}$ for 30 minutes. The $\mathrm{p}^{\mathrm{H}}$ of the solution was checked by adding $5 \mathrm{ml}$ of $0.561 \mathrm{~N} \mathrm{HCl}\left(\mathrm{p}^{\mathrm{H}}\right.$ was between $4.1-4.8$ by adjusting with $5 \% \mathrm{NaOH}$ or $5 \% \mathrm{HCl}$ ). Incubation with amyloglucosidase was done by adding $0.3 \mathrm{ml}$ of amyloglucosidase solution and incubating at $60^{\circ} \mathrm{C}$ for 30 minutes.

For Insoluble Dietary Fiber Filtrations, 3ml of distilled water was added to the celite and drawn with suction pump to make the celite even material at the bottom of the fritted crucible. The enzyme mixture was filtered into the filtration flask through the fritted crucible. The residue was washed two times with $10 \mathrm{ml}$ of distilled water (pre-heated to $70^{\circ} \mathrm{C}$ ) and the filtrate kept for Soluble Dietary Fiber (SDF) determination. Two $10 \mathrm{ml}$ of $95 \%$ ethanol and acetone each were used to wash the residue twice. The residue was dried overnight at $103^{\circ} \mathrm{C}$ in the oven and cooled in the desiccators for 1 hour. It was weighed and the volume obtained is the insoluble dietary fiber content. To determine the Soluble Dietary Fiber, 4 volumes of $95 \%$ ethanol preheated to $60^{\circ} \mathrm{C}$ were added to the filtrate from IDF. Precipitate was allowed to form at room temperature for 60 minutes. And $8 \mathrm{~g}$ of combined filter and wash water washings with $320 \mathrm{ml}$ preheated at 60 degree $\mathrm{C}$ of ethanol for 60 minutes. The precipitate was filtered by first weighing the crucible to the nearest $0.1 \mathrm{mg}$, wetting and redistributing the celite bed in the crucible with $15 \mathrm{ml}$ of $78 \%$ ethanol using the wash bottle as well as applying suction to the crucible to draw the celite onto fritted crucible as even material. The precipitated enzyme digest from insoluble dietary fiber was filtered through the fritted crucible and $78 \%$ ethanol was used to transfer the digest into the crucible. The washing would then be done twice by using $15 \mathrm{ml}$ of $78 \%$ ethanol, $15 \mathrm{ml} 95 \%$ ethanol as well as $15 \mathrm{ml}$ acetone each. The crucibles containing residue was dried overnight at $103^{\circ} \mathrm{C}$.

Note: Blank test was run for each of the analysis in order to determine the effect of the chemicals on the result.

\subsubsection{Calculations}

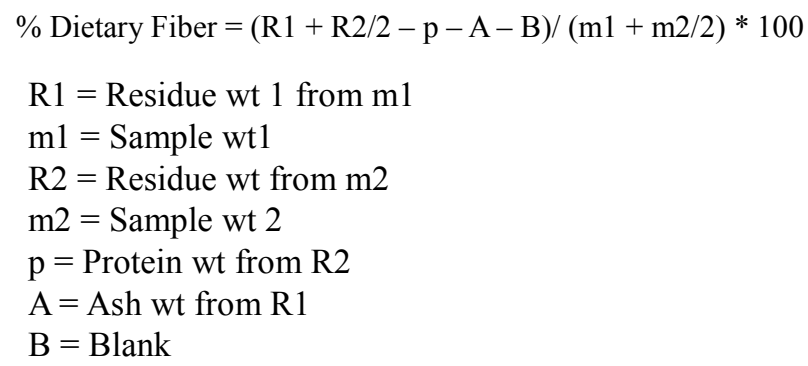

\subsection{Sensory Evaluation}

In-house Consumer-oriented Test was conducted to determine product acceptability using scoring test with the aid of 9-point hedonic scale. The sensory characteristics of the product such as colour, taste, aroma, mouth-feel and general acceptability were examined by a team of twenty (20) semi-trained panelists drawn from staff of the college who are familiar with the product. Sample presentation was randomized and presented to each penalist at the same time using identical containers. Sensory Booth was fitted with lightening that support visual judgement of the penalist on colour attribute of the new product. Each penalist was asked to score each coded sample based on a nine-point hedonic scale.

\subsection{Statistical Analysis}

The data obtained from different analyses were subjected to various statistical analyses which include simple descriptive mean, standard deviation and Analyses of Variance (ANOVA), while Duncan's test was used to separate the means and correlation among the sample's attributes examined using SPSS 17.0 Software.

\section{Results and Discussion}

\subsection{Proximate Composition of Bambaranut - Tigernut- Coconut Milk Beverage Blends}

The results in table 1 show the proximate composition of milk beverage produced from single extraction and mixed blends of bambaranut - tigernut - coconut. Significant $(\mathrm{P}<0.05)$ difference existed among the proximate composition of the samples studied. The moisture content of the milk beverage blends ranged from $81.04-81.22 \%$. The values within this range were higher than $79.24-79.29 \%$ (control samples). Belewu and Belewu ${ }^{(2)}$ reported 92.27\%, $89.8 \%$ and $91.63 \%$ for single milk extraction from tigernut, 
bambaranut and coconut respectively. The variation shown in the moisture content reported in earlier research works and present research could be due to different methods of extraction employed and varied ratios used during blending of mixed milk beverage. In addition, the moisture indicated was higher showing that further preservation may be required. The crude protein varied significantly among the samples. The blend made from ratio 3:2:1 (BTC-B $\left.)_{2}\right)$ of bambaranut-tigernut-coconut had the highest value of protein, but lower than $6.28 \%$ of single milk extraction from bambaranut. This observation could be due to highest ratio (3) of bambaranut milk extract in the bland (BTC-B $)_{2}$. Akande, et al ${ }^{(17)}$ stated that bambara groundnut contained $20.05-$ $22.54 \%$ protein. However, the crude protein found in the milk beverage blend was higher than $3.20 \%$ and $3.40 \%$ for coconut-natural milk blend and cow milk respectively ${ }^{(20)}$.
The fat content of the milk beverage blends ranged from 3.09\% to $4.30 \%$. These values were higher than $2.30 \%$ value obtained from $100 \%$ bambaranut milk beverage. The crude fat of the beverage blends was in agreement with the findings of Rehman, et al ${ }^{(20)}$ who reported $2.36 \%$ and $3.82 \%$ from coconut-natural milk blend and cow milk respectively. The ash content is a measure of mineral elements in a food and important nutrients in human body ${ }^{(27)}$. The ash values of blend samples were between $1.28-2.09 \%$. The single milk extraction from bambaranut had the highest $(2.30 \%)$ value. The ash content in the milk beverage sample was within the standard limit of $<5 \%$ (SON). The crude fiber obtained on the samples ranged from $0.88-2.12 \%$ and the total carbohydrates was between $5.76-11.82 \%$. The indication from the results further appreciated the nutritional value of mixed milk beverage of vegetable origin.

Table 1. Proximate Composition of Bambaranut - Tigernut - Coconut Milk Beverage Blends

\begin{tabular}{|c|c|c|c|c|c|c|}
\hline Blend of Milk Beverage & * Moisture \% & * Protein \% & * Fat $\%$ & * Crude Fiber \% & * Ash \% & * Carbohydrate $\%$ \\
\hline BTC-B & $81.04^{\mathrm{a}} \pm 0.01$ & $4.13^{\mathrm{c}} \pm 0.01$ & $3.09^{\mathrm{c}} \pm 0.01$ & $1.37^{\mathrm{d}} \pm 0.01$ & $1.28^{\mathrm{e}} \pm 0.01$ & $9.29^{\mathrm{b}} \pm 0.04$ \\
\hline BTC-B ${ }_{2}$ & $81.22^{\mathrm{a}} \pm 0.01$ & $5.29^{\mathrm{b}} \pm 0.01$ & $3.51^{\mathrm{b}} \pm 0.01$ & $1.99^{\mathrm{b}} \pm 0.01$ & $2.09^{\mathrm{b}} \pm 0.01$ & $5.90^{\mathrm{d}} \pm 0.02$ \\
\hline BTC-B 3 & $81.09^{\mathrm{a}} \pm 0.01$ & $5.10^{\mathrm{b}} \pm 0.01$ & $4.30^{\mathrm{a}} \pm 0.02$ & $1.81^{\mathrm{b}} \pm 0.01$ & $1.94^{\mathrm{c}} \pm 0.02$ & $5.76^{\mathrm{d}} \pm 0.01$ \\
\hline BTC-B 4 & $81.11^{\mathrm{a}} \pm 0.01$ & $4.66^{c} \pm 0.01$ & $3.67^{\mathrm{b}} \pm 0.01$ & $1.50^{\mathrm{c}} \pm 0.01$ & $1.67^{\mathrm{d}} \pm 0.01$ & $7.39^{c} \pm 0.02$ \\
\hline TM-Control & $79.29^{b} \pm 0.01$ & $3.81^{\mathrm{d}} \pm 0.01$ & $3.12^{\mathrm{c}} \pm 0.02$ & $0.88^{\mathrm{e}} \pm 0.01$ & $1.08^{\mathrm{f}} \pm 0.03$ & $11.82^{\mathrm{a}} \pm 0.01$ \\
\hline BM-Control & $79.24^{\mathrm{b}} \pm 0.02$ & $6.28^{\mathrm{a}} \pm 0.01$ & $2.04^{\mathrm{d}} \pm 0.02$ & $2.12^{\mathrm{a}} \pm 0.01$ & $2.30^{\mathrm{a}} \pm 0.01$ & $7.48^{\mathrm{c}} \pm 0.03$ \\
\hline LSD & 0.01186 & 0.00981 & 0.09262 & 0.00667 & 0.02169 & 0.02880 \\
\hline
\end{tabular}

* Mean of triplicate sample, mean score with different superscript letters a - $\mathrm{f}$, are significantly different $(\mathrm{P}<0.05)$ along the column Key:

BTC-B B $_{1}=$ Milk beverage blend of 1:1:1 ratio of bambaranut: tigernut: coconut extract BTC-B $\mathrm{B}_{2}=$ Milk beverage blend of 3:2:1 ratio of bambaranut: tigernut: coconut extract BTC- $\mathrm{B}_{3}=$ Milk beverage blend of 2:1:3 ratio of bambaranut: tigernut: coconut extract BTC- $\mathrm{B}_{4}=$ Milk beverage blend of 1:3:2 ratio of bambaranut: tigernut: coconut extract TM-Control $=$ Milk beverage contained $100 \%$ tigernut extract BM-Control $=$ Milk beverage contained $100 \%$ bambaranut extract

\subsection{Comparison between Crude and Dietary Fiber of Milk Beverage Blends}

Comparison between crude and dietary fiber of milk beverage blends from mixture of milk extracted from bambaranut - tigernut - coconut at varied ratios is presented in Table 3. The result showed significant difference $(\mathrm{P}<0.05)$ among the blends and control samples formulated. The crude fiber $1.37-1.99 \%$ range was shown among the blends. The value in this range was higher than the values within the range of $1.12-1.88 \%$ total dietary fiber of similar sample blends. Again, insoluble dietary fiber of $0.80-1.10 \%$ range was also higher when compared with values within the range of $0.32-0.78 \%$ range of soluble dietary fiber of the same sample blends. The difference between crude and dietary fiber of the same blend could be due to the method used in the determination which differed. Nutritionally, dietary fiber represents the true fiber that human body can gain from consumption of food and food products ${ }^{(27)}$.

Table 2. Crude and Dietary Fiber of Bambarnut - Tigernut - Coconut Milk Beverage Blends

\begin{tabular}{|c|c|c|c|c|}
\hline Blend of Milk Beverage & Crude Fiber \% & Insoluble Dietary Fiber \% & Soluble Dietary Fiber \% & Total Dietary Fiber \% \\
\hline BTC-B 1 & $1.37^{\mathrm{d}} \pm 0.01$ & $0.91^{\mathrm{d}} \pm 0.03$ & $0.38^{\mathrm{d}} \pm 0.02$ & $1.29^{\mathrm{d}} \pm 0.02$ \\
\hline BTC-B 2 & $1.99^{\mathrm{b}} \pm 0.01$ & $1.10^{\mathrm{b}} \pm 0.01$ & $0.78^{\mathrm{b}} \pm 0.02$ & $1.88^{\mathrm{b}} \pm 0.01$ \\
\hline BTC-B 3 & $1.81^{\mathrm{b}} \pm 0.01$ & $1.02^{\mathrm{c}} \pm 0.02$ & $0.69^{c} \pm 0.03$ & $1.71^{\mathrm{c}} \pm 0.02$ \\
\hline BTC-B 4 & $1.50^{\mathrm{c}} \pm 0.01$ & $0.80^{\mathrm{e}} \pm 0.02$ & $0.32^{\mathrm{e}} \pm 0.01$ & $1.12^{\mathrm{e}} \pm 0.01$ \\
\hline TM-Control & $0.88^{\mathrm{e}} \pm 0.01$ & $0.50^{\mathrm{f}} \pm 0.02$ & $0.28^{\mathrm{f}} \pm 0.02$ & $0.78^{\mathrm{f}} \pm 0.01$ \\
\hline BM-Control & $2.12^{\mathrm{a}} \pm 0.01$ & $1.24^{\mathrm{a}} \pm 0.03$ & $0.86^{\mathrm{a}} \pm 0.02$ & $2.10^{\mathrm{a}} \pm 0.03$ \\
\hline LSD & 0.00667 & 0.00471 & 0.00471 & 0.00471 \\
\hline
\end{tabular}

* Mean of triplicate sample, mean score with different superscript letters $(\mathrm{a}-\mathrm{f})$ are significantly different $(\mathrm{P}<0.05)$ along the column Key:

BTC-B $B_{1}=$ Milk beverage blend of 1:1:1 ratio of bambaranut: tigernut: coconut extract BTC- $\mathrm{B}_{2}=$ Milk beverage blend of 3:2:1 ratio of bambaranut: tigernut: coconut extract 
BTC- $\mathrm{B}_{3}=$ Milk beverage blend of 2:1:3 ratio of bambaranut: tigernut: coconut extract BTC-B ${ }_{4}=$ Milk beverage blend of 1:3:2 ratio of bambaranut: tigernut: coconut extract TM-Control $=$ Milk beverage contained $100 \%$ tigernut extract

BM-Control $=$ Milk beverage contained 100\% bambaranut extract

Table 3. Mean Scores for Sensory Characteristics of Bambaranut - Tigernut - Coconut Milk Beverage

\begin{tabular}{|c|c|c|c|c|c|c|}
\hline Blend of Milk Beverage & Blending Ratio & *Colour of Sample & *Aroma of Sample & *Taste of Sample & *Mouth-Feel & * Overall Acceptability \\
\hline BTC-B $_{1}$ & $1: 1: 1$ & $7.30^{\mathrm{abc}}$ & $6.80^{\mathrm{ab}}$ & $7.20^{\mathrm{ab}}$ & $6.90^{\mathrm{ab}}$ & $7.30^{\mathrm{b}}$ \\
\hline BTC-B ${ }_{2}$ & $3: 2: 1$ & $7.70^{\mathrm{ab}}$ & $6.80^{\mathrm{ab}}$ & $5.60^{\mathrm{d}}$ & $6.00^{\mathrm{bc}}$ & $6.60^{\mathrm{bc}}$ \\
\hline $\mathrm{BTC}^{-\mathrm{B}_{3}}$ & $2: 1: 3$ & $6.60^{\text {cd }}$ & $6.30^{\mathrm{b}}$ & $6.80^{\mathrm{bc}}$ & $6.40^{\mathrm{abc}}$ & $6.30^{\mathrm{bc}}$ \\
\hline $\mathrm{BTC} \mathrm{B}_{4}$ & $1: 3: 2$ & $6.40^{\mathrm{cd}}$ & $8.10^{\mathrm{a}}$ & $8.10^{\mathrm{a}}$ & $7.70^{\mathrm{a}}$ & $8.60^{\mathrm{a}}$ \\
\hline TM-Control & $100 \%$ & $6.00^{\mathrm{d}}$ & $6.70^{\mathrm{ab}}$ & $8.20^{\mathrm{a}}$ & $7.40^{\mathrm{a}}$ & $7.10^{\mathrm{bc}}$ \\
\hline BM-Control & $100 \%$ & $8.30^{\mathrm{a}}$ & $5.70^{\mathrm{b}}$ & $6.00^{\mathrm{cd}}$ & $5.50^{\mathrm{c}}$ & $5.90^{\mathrm{c}}$ \\
\hline LSD & & 0.58787 & 0.64521 & 0.56470 & 0.6333 & 0.6492 \\
\hline
\end{tabular}

* Mean of 20 penalists, mean score with different superscript letters $(a-d)$ are significantly different $(P<0.05)$ along the column Key:

BTC-B $\mathrm{B}_{1}=$ Milk beverage blend of 1:1:1 ratio of bambaranut: tigernut: coconut extract

BTC-B $B_{2}=$ Milk beverage blend of 3:2:1 ratio of bambaranut: tigernut: coconut extract

BTC-B ${ }_{3}=$ Milk beverage blend of 2:1:3 ratio of bambaranut: tigernut: coconut extract

BTC- $\mathrm{B}_{4}=$ Milk beverage blend of 1:3:2 ratio of bambaranut: tigernut: coconut extract

TM-Control $=$ Milk beverage contained 100\% tigernut extract

BM-Control $=$ Milk beverage contained $100 \%$ bambaranut extract

\subsection{Sensory Characteristics of Milk Substitute Blends}

The mean scores of sensory characteristics of milk beverage from bambaranut - tigernut - coconut blends are presented in table 3 . The indication from this result showed significant difference $(\mathrm{P}<0.05)$ on the characteristics of the blends evaluated. Rehman, et al ${ }^{(20)}$ reported significant difference on similar sensory properties of coconut-natural milk blends. The colour of the milk beverage indicated that single bambaranut milk extract (BM-Control) had the highest score of 8.30 and blend (BTC-в2) made with maxing ratio $(3: 2: 1)$ milk extracted from the three raw materials had 7.70. The single milk extract from tigernut (TM-Control) scored the least value (6.0). Similarly, significant mean difference was discovered on the aroma, taste and mouth-feel of the milk beverage blends. The blend made from mixing ratio of 1:3:2 $\left(\mathrm{BTC}^{\left.-\mathrm{B}_{4}\right)}\right.$ had mean score of 8.10 each for aroma and taste respectively. The 7.40 mean score for the mouth-feel was the highest rated among the blends by the opinion of judges. Generally, the blend made from ratio 1:3:2 of bambaranut - tigernut coconut milk mix had the highest mean score of 8.60 was the most rated and the best among the sample blends. The significant difference observed in the characteristics of milk beverage blends and the single extraction from bambarnut, and tigernut respectively may be caused by the variation of the inherent chemical properties and the nature of the raw material used. However, the results obtained further indicated the potential of vegetable plant materials in the development of acceptable milk analogue.

\section{Conclusion}

This study showed that non-dairy milk beverage produced from mixed blends of aqueous extracts from bambaranut - tigernut - coconut with improved nutritional quality was obtained from this work. The proximate composition and dietary of milk beverage blends when compared with the standards found in dairy whole milk will give good nutritional quality, most especially in rural communities in developing countries where accessibility and cost of dairy products as a whole are major challenges of the people. The results from sensory evaluation revealed that the consumer acceptability of the beverage was varied based on the opinion of the judges. These observations further support most of the earlier revelations on milk analogue from vegetable source as means of alleviating malnutrition in most developing countries such as Nigeria.

\section{Recommendations}

- Nutritional public enlightenment on the method of preparation and the nutritional quality of milk from vegetable source (such as bambaranut, tigernut, coconut, etc) should be conducted both at the local communities and the cities of the developing countries.

- $\quad$ There is need to examine the quality of the protein found in this work.

\section{References}

[1] Adedokun I.I, Okorie S.U, Onyeneke E.N and Anoruo S.A, (2013): Evaluation of Yield, Sensory and Chemical Characteristics of Soft Unripened Cheese produced with partial incorporation of Bambaranut Milk. Academia Journal of Food Research 1(1): $014-018$.

[2] Belewu M.A and Belewu K.Y (2007): Comparative Physico-Chemical Evaluation of Tigernut, Soyabean and Coconut Milk Sources. Int. J. Agri. Boil., 9(5): 785 - 787. 
[3] Singh T and Bains G.S (1998): Grain Extract-Milk Beverage, Processing and Physico-Chemical Characteristics. J. Food Sci., 53:1387 - 1390 .

[4] Akubor, P.I (1998): Physico-chemical and Sensory Characteristics of Melon Seed Milk. J. Food Sci,; 35: 93 95.

[5] Sun-young P, K.S Marsh, Y.S Jenny and S.E Yun (2000): A Study on a Processing Method to Improve SoyMilk Quality. Proceedings of Pre-congress Internet Conference, May 8, Dec. 31, pp:31-32.

[6] Obizoba I.C and Egbunna H.I (1992): Effect of germination of Fermentation on the Nutritional Quality of Bambaranut (agndzie subterranean Thourars) and its Products (Milk). Plant Foods Hum. Nutr., 42:13 - 23.

[7] Obizoba I.C and J.U Anyika (1995): Nutritive Value of Baobab Milk (Adansoniadigitata L), Hungary Rice, Acha (Digitannaexillis) Flours. Plant Foods for Hum. Nutr., $46: 156-165$.

[8] Odo F.O (2001): Consumer Acceptance of Groundnut Milk. Proceedings of the $25^{\text {th }}$ Annual Conference of the Nigerian Institute of Food Sci. and Tech. (NIFST). November 5 - 9, Lagos, Nigeria, pp. 135 - 137.

[9] Ukwuru M.U, Omachona L.J and Onokah N (2008): Production and Quality Assessment of Tigernut (Cyperus esculentus) Imitation Milk during Storage. J. Food Sci. Technol., 45:180 - 182 .

[10] Osagie A.U and S.A Eka (1998): Lipid from Plant Source, Structure and Distribution. Proc. 1st Agric. Conf. on Biochemistry of Lipids; 103:21 - 26.

[11] Temple V.J, T.O Ojobe and N.M Kapu (1990): Chemical Analysis of Tigernut (Cyperus esculentus). J. Sci. Food Agric., 50:262 - 263

[12] Temple V.J (1998): Lesser Known Plant Foods. In: Nutritional Quality of Plant Foods. J. Food Tech., 35:93 95.

[13] Ojobe T.O and Tempo V.J (1983): Amino Acid Composition of Tigernut Tubers (Cyperus esculentus). Nig. J. Sci. Biotechnol., 2:35 - 38 .

[14] FAO/WHO (2002a): Milk and Milk Products. Joint FAO/WHO Food Standards Programme. CODEX Alimentarius Commossion, Pp:42.

[15] FAO/WHO (2002b): Joint FAO/WHO Expert Report on Diet, Nutrition and the Prevention of Chronic Diseases, cited in Food and Nutrition Bulletin, 24: $255-256$.

[16] Bosch L, Alegria A and Farri R (2005): RP-HPLC Determination of Tigernut and Orgeat Amino Acid Contents. Food Sci. Tech. Inter., 11:33-40.
[17] Akande K.E, Abubakar M.M, Adegbola T.A, Bogoro S.E, Doma U.D and 2E.F. Dabiyi (2009): Nutrient Composition and uses of Bambara groundnut (Vignia substerranea (L.) Verdcourt. Continental J. Food Sci. Tech 3:8-13.

[18] Goli A.E (1995): Bambara Groundnut, Bibliographical Review. In: Bambara Groundnut (Vigna subterranean (L.) Verdc.). Promoting the Conservation and use of Underutilized and Neglected Crops. (Editors: Heller J, Begemann $F$ and Mushonga J). Proceedings of the workshop on Conservation and Improvement of Bambara Groundnut (Vigna subterranean (L.) Verdc.), $14-16^{\text {th }}$ November, 1995, Harare, Zimbabwe, pp. 84 - 86.

[19] Omoikhoje S.O and Arijeniwa A (2004): Effect of Heat Treatments on Proximate and Mineral Compositions of Bambara Groundnut (Vigna subterranea). In: Sustaining Livestock Production under Changing Economic Fortunes. (Editors: Tukur H.M, Hassan W.A, Maigandi S.A, Ipinjolu J.K, Daneji A.I, Baba).

[20] Rehman S, Mushtaq A.M, Yameen A, Almas K and muntaha S (2004): Sensory and Nutritional Evaluation of CoconutNatural Milk Blend. Pak. J. Life Soc. Sci. 2(2): $104-108$.

[21] Parsley J.G (1992): Replanting of the Tree of Life, CAB International Wallingford Oxon, pp. $38-40$.

[22] Nieuwentus R, Nieuwelink J (2002): Agrodok Series No. 10 CTA: The Netherlands, Pp. $28-30$

[23] Thai Food Composition (2004): Institute of Nutrition, Mahidol University (INMU), Thailand, p 150.

[24] Udeozor L.O (2012): Tigernut-Soy Milk Drink: Preparation, Proximate Composition and Sensory Qualities. International Journal of Food and Nutrition Science, Vol. 1(4), pp 18 - 26.

[25] A.O.A.C (2000): Official Methods of Analysis. Association of Official Analytical Chemist, 17th Edition, Washington D.C.

[26] A.A.C.C (2000): Approved Methods of the American Association of Cereal Chemists, 10th ed. The Association, St. Paul, MN, 2000.

[27] Onyeka E.U (2008): Mineral Elements and their Importance in: Food and Nutrition. 2nd Edition. Charismatic Publisher, Owerri.

[28] Belewu M.A and Abodurin O.A (2005): Preparation of Kunnu from Unexploited.

[29] Mason D (2005): Tigernuts. Retrieved from www.google.com on $9 / 08 / 2008$.

[30] Adgidzi, E.A, Ingbian E.K, Abu J.O, (2011): Effects of Hot Water and Steam Blanching on the Quality of Acqueous Extract from Tigernuts (Cyperus esculentus) PAT June 2011; 7(1): $90-102$. 